\title{
DISCOURSE ON RELATIONS BETWEEN INDONESIA AND PAPUA: CONTENT ANALYSIS OF HISTORY TEXTBOOK OF 2013 CURRICULUM
}

\author{
Susanto T. Handoko ${ }^{1}$, Wasino ${ }^{2}$ \\ ${ }^{1}$ History Education Study Program, Faculty of Teacher Training and Education, \\ Universitas Cenderawasih Jayapura \\ ${ }^{2}$ Department of History, Faculty of Social Sciences, Universitas Negeri Semarang
}

\begin{abstract}
This research is motivated by the existence of a national identity crisis in Indonesian society, especially in young people or students. This research aims to analyze the discourse on relations between Indonesia and Papua found in a history textbook for senior high school of 2013 curriculum. Through this research, an understanding of how the state reconstructs national identity (Indonesian-ness) and local identity (Papuan-ness) in a history textbook for senior high school used by senior high school students in Jayapura City. The research method used is the qualitative method, which focuses on the content analysis of the history textbook. This analysis will focus on the relations between Indonesia and Papua. The meaning process was conducted using two concepts, namely Indonesian-ness and Papuan-ness. Then, those two concepts were represented in three themes: ethnic nationalism, nationalism, and national integration. The results of the research showed that the discourse on national identity (Indonesian-ness) and local identity (Papuan-ness) was a product of the government's political policies in education, namely ideology and state identity.
\end{abstract}

Keywords: Discourse, Relations between Indonesia and Papua, Content Analysis, History Textbook for Senior High School, 2013 Curriculum

\begin{abstract}
ABSTRAK
Penelitian ini dilatarbelakangi oleh adanya krisis identitas nasional di masyarakat Indonesia, terutama pada kaum muda atau pelajar. Penelitian ini bertujuan untuk menganalisis wacana tentang hubungan Indonesia dan $\mathrm{Pa}$ pua yang ditemukan dalam buku teks sejarah untuk kurikulum SMA 2013. Melalui penelitian ini, pemahaman tentang bagaimana negara merekonstruksi identitas nasional dan identitas lokal dalam buku teks sejarah untuk SMA yang digunakan oleh siswa SMA di Kota Jayapura. Metode penelitian yang digunakan adalah metode kualitatif, yang berfokus pada analisis isi buku teks sejarah. Analisis ini akan fokus pada hubungan antara Indonesia dan Papua. Proses pemaknaan dilakukan dengan menggunakan dua konsep, yaitu keindonesiaan dan ke-Papua-an. Kemudian, kedua konsep tersebut diwakili dalam tiga tema: nasionalisme etnis, nasionalisme, dan integrasi nasional. Hasil penelitian menunjukkan bahwa wacana tentang identitas nasional dan identitas lokal adalah produk kebijakan politik pemerintah dalam pendidikan, yaitu ideologi dan identitas negara.
\end{abstract}

Kata kunci: wacana, relasi Indonesia dan $\mathrm{Pa}-$ pua, analisis isi, buku teks sejarah SMA, Kurikulum 2013 


\section{INTRODUCTION}

The understanding and meaning ability of Senior High School students in Jayapura City (Papua) towards the relations between Indonesia and Papua are obtained from learning processes. One of them is through studying history (history books). History textbook for senior high school is one of many sources that are dominant in school because it provides historical events (stories). History textbook for senior high school has a vital contribution because it involves the formation of cognitive and affective aspects of students. Therefore, in writing a history textbook for senior high school, synchronization between academic history and history for educational purposes is needed. It means the integration between values internalization as representations of certain ideologies and critical studies that the inculcation of values (ideologies) is not indoctrinated. Discourse is a construction of reality so that the subjectivity and interests of discourse constructor also play a role in it. History can be considered as a system of discourse (history) that is bound by its context (time). Thus, the discourse must be viewed critically because discourse is not neutral. History textbook is a part of the practice of discourse (Utami \& Widiadi, 2016, pp. 107-109)

The research on the Indonesian history textbook was carried out by several academics from various universities in Indonesia. The research concerning the Indonesian history textbook in the two decades of the reform era was conducted by Wirasti (2001), who examines various themes of a state ideology that appeared in a history textbook in the period of 19752001. One of them is the nationalism / unity theme. The next researcher is Purwanta (2012), who critically reviews the national ideology discourse contained in the history textbook in the period of 1975 2008, which is constructed as a substitute for local identity. Purwanta (2013) also suggests that the ideology of militarism is very dominant in writing a history textbook in Indonesia in the period of 19751994. Purwanta's research results were strengthened by the research conducted by Mulyana (2013), which interestingly reviews the themes of nationalism and militarism that dominated the writing of the Indonesian National History textbook (SNI). The discourse on nationalism is considered very dominant in a history textbook, especially in the narratives concerning the formation of the nation-state. While the discussion on militarism is very assertive in the narratives concerning the struggle in Indonesian National History. Furthermore, Utami \& Widiadi's research (2016) concerning the value of Unity in Diversity (Bhinneka Tunggal Ika) in the history textbook of the 2006 curriculum was represented in various themes. The themes are acculturation, multiculturalism, discrimination, and unity. The political policies of education strongly influenced the practice of discourse in the history textbook carried out by the government (Mulyana, 2013).

Various research of Indonesia's foremost history education academics above has interestingly discussed the various discourses in the textbook for senior high school concerning Indonesian History from $1975,1984,1994$ to 2006 Curricula. However, none has specifically addressed the discourse on relations between Indonesia and Papua. Whereas, the relations between Indonesia (Jakarta) and Papua (Jayapura) often lead to a conflict of interest and controversy in the dynamics of the struggle of Indonesian people to uphold national integration. Issues or various problems in Papua have local, national, and international dimensions. Papua has an essential and strategic meaning in the dynamics of Indonesia's development in the past, present, and future.

Various research on history textbook that has been conducted by researchers above shows that history education has a major contribution in the formation of the dignified character and civilization of the nation as well as in the formation of Indonesian people who have a sense of nationality and love for the country (Hasan, 2012, p. 87). History education has great potential in developing character 
education, especially nationalism. Through education, community, nation, or country seeks to build resilience so that the entity and its values remain and develop. In this context, education has a meaning as an effort to transmit and transform the values upheld and identity of the community. By instilling national identity and spirit, it is expected that students will become good and responsible citizens (Suryadi., Hayat., Rustana. \& Abduhzen, 2014, p. 5)

This research aims to analyze the discourse on the relations between Indonesia, and Papua found in the history textbook for senior high school of 2013 Curriculum. Through this research, an understanding of how the state reconstructs national identity (Indonesian-ness) and local identity (Papuan-ness) in the history textbook used by senior high school students in Jayapura City (Papua) will be obtained. The textbook is one of the learning resources used in learning history in school. History learning functions to preserve collective memory and values that are considered essential, such as the value of Indonesian-ness (national identity) and Papuanness (local identity).

\section{RESEARCH METHOD}

This research is a qualitative study that examines the discourse of the relations between Indonesia and Papua (the reconstruction of national and local identity) through the content of the Indonesian history textbook for senior high school of 2013 Curriculum. In this context, the textbook is placed as a historical document containing the author's "subjective expression" related to interest (power) as a context in the production and reproduction of discourses, assumptions, ideologies, and messages delivered (and discussed) by the author to students as the readers (Purwanta, 2012, p. 111).

The research method used in this research was the content analysis method. The content analysis method is a method used for collecting and analyzing the contents of a text. The text in question in this research is the historical narratives con- tained in the Indonesia history textbook for senior high school students. Therefore, the data source of this research is the Indonesian history textbook of 2013 Curriculum for Grade X, XI, and XII of the senior high school published by the Ministry of Education and Culture of the Republic of Indonesia. The selection or the reason why this textbook is chosen to be the source of the data is that this textbook is an official book (Hasan, 2012, p. 29) published by the Indonesian government so that government or state policies in interpreting historical narratives are obvious and easily analyzed (Mulyana, 2013, p. 80).

The analysis technique used by the researchers in this analysis method was meaning to the narratives contained in the Indonesian history textbook for grade $\mathrm{X}$, XI, and XII of senior high school. The meaning process was carried out using two main concepts, namely Indonesianness and Papuan-ness. Researchers considered these two concepts to contain ideologization in providing meaning to historical events narrated in the history textbook. Furthermore, the two main concepts were then represented in three themes, namely: ethnic nationalism, nationalism, and national integration.

\section{RESULTS AND DISCUSSION Historical Review of The Relations Be- tween Indonesia and Papua}

The relations between Indonesia and $\mathrm{Pa}$ pua have been traced historically since the Dutch colonization in Papua from 1896 to 1962. Even in the 16th century, the sultans of Maluku had instilled their influence in the western region of the island of Nieuw Guinea (Papua), known as the Raja Ampat Islands, namely Waigeo, Salawati, Misool, and Waigama Islands. The King of Waigama and Misool were under the influence of Sultan Bacan. Waigeo and Salawati Islands became the object contested by the Sultan of Ternate and the Sultan of Tidore. The competition between the two empires had an impact on the efforts to expand the domains of those two empires. Sultan of Ternate expanded 
his power to Sulawesi and the islands in the west of Halmahera. Sultan Tidore extended his power to East Seram, western Nieuw Guinea, and all islands between Nieuw Guinea and Halmahera (Sinaga, 2013, p. 3; Widjojo (Ed), 2009, pp. 95113).

The proclamation of Indonesia's Independence on August 17th, 1945, had an impact on the relations between Indonesia and Papua. According to the declaration on August 17th, 1945, the territory of the Republic of Indonesia was the entire territory of the former Dutch East Indies. According to the decision of the Preparatory Committee for Indonesian Independence (PPKI) meeting on August 18th, 1945 , the area covered Sumatra, Java, Kalimantan, Sulawesi, West Nusa Tenggara, East Nusa Tenggara, and Maluku - in this context Papua was included in Maluku.

Papua has been integrated into the Republic of Indonesia since May 1st, 1963, and has built a unique relationship with the central government (Jakarta) until now. Generally, political issues in $\mathrm{Pa}-$ pua are limited to the independence of Papua or the discussion, whether it remains integrated into the Unitary State of the Republic of Indonesia (NKRI). The issue of conflict concerning national integration in Papua can be traced from various interrelated aspects such as politics, economy, social culture, and defense and security. According to Widjojo (Ed.) (2009), the complexity of the Papua issue at local, national, and in the context of the conflict in Papua, focuses on four main topics or problems. Firstly, the marginalization problem and discriminatory effects towards indigenous Papuans due to economic development, political conflicts, and mass migration to Papua since 1970. Secondly, the failure of development, especially in the fields of education, health, and empowerment of the people's economy. Thirdly, there is a historical contradiction in the construction of political identity between Papua and Jakarta. Fourthly, the accountability for past violence against Indonesian citizens in Papua conducted by the state. In the view of
Widjojo (Ed.) (2009, pp. 227-228), if the Papuan problem is portrayed in an ideological perspective, then the basis of all problems or issues is the "Problems Concerning the Relationship in the Meaning of Indonesian-ness and Papuan-ness."

Historical review of the dynamics of the relations between Indonesia and $\mathrm{Pa}$ pua since the integration of Papua into the Republic of Indonesia revealed "two faces" which are dominant (Aditjondro, 2000, pp. 5-32; Meteray, 2012, pp. 53-112 \& 169 -258; Kaisiepo, 1999, pp. 167-187; Rahab, 2006, pp. 3-23; Widjojo (Ed.), 2009, pp. 142), namely Papuan Nationalism (Free Papua) and Indonesian Nationalism (proNKRI). These two faces of nationalism in Papua will undoubtedly weaken the building process of Indonesian-ness in the Land of Papua if not appropriately managed by the Central Government.

The contestation of Papuan-ness and Indonesian-ness identities certainly affected young people in Papua to understand and interpret the relationship between Papua and Indonesia. The ability of young people (high school students) to understand and interpret can be constructed through history learning. To overcome various conflicts, violence, and eroded national indicators that have threatened national integration, especially in the Land of Papua. The root of the problems that must be explored and restructured, namely, the awareness of Indonesian-ness needs to be improved, especially among younger generations (high school students). Therefore, history education will have essential contributions in fostering national awareness among young people, especially in the current era. In the context of this research, history education is represented from the Indonesian history textbook of 2013 Curriculum for senior high school students.

\section{The Approach Used In The Textbook}

The textbook is a source and medium used to deliver subject materials to students. History textbook is a source and medium for teachers to provide articles related to events that have occurred in the 
past (Budiono \& Awaludin, 2017, p. 36). History subject is one of the dominant means (media), which can instill the discourse on state ideology and national identity. One of the instruments used in this practice is the history textbook. History textbook is arranged according to a curriculum set by the state and is a part of official history. The preparation of the curriculum is based on political foundations, namely, governmental policies of the government. One of the many influences given by the textbook is the ideologization and national identity. The textbook represents various state ideologies. The ideological forms in the national history textbook are nationalism, constitutionalism, militarism, anti-communism, anti-New Order, democracy, stability, development, and economic globalization (Mulyana, 2013: 78; Purwanta, 2013, p.88).

One form of the ideologization of the Indonesian National History textbook is Nationalism (Indonesian-ness), which is a political concept. According to Gardiner (in Mulyana, 2013, p. 81), a political approach (political history) has a dominant characteristic in the study of the power activity (organization) in society in the past. For examples are Hindu-Buddhist and Islamic-style kingdoms in the preIndonesian independence era.

The 2013 curriculum is designed to strengthen student's competencies in aspects of knowledge, skills, and attitudes comprehensively. Indonesian history subject for senior high school students is designed to follow this formula. Indonesian history subject is one of the subjects that must be learned by all students. As a compulsory subject, the Indonesian history textbook is prepared with a more popular regressive approach (Sardiman \& Lestariningsih, $2014 \& 2017$, p. iii). According to the textbook, students are invited to see (observe) historical phenomena in their daily lives in the surrounding environment, which contain socio-cultural aspects and historical heritages, then they are related to past events with various points of view. Indonesian history subject equips students with knowledge about space and time dimensions of Indonesian history dynamics, skills in presenting the experience they master in an abstract and concrete manner, as well as an attitude of respecting the struggle of heroes so that the mindset of students who are aware of history is formed (Abdurakhman, Pradono., Sunarti., \& Zuhdi, 2018: iii). By studying history, students are expected to be able to take the values of every historical event that occur to strengthen the patriotism and pride as well as to improve their nationalism (Gunawan, Lestariningsih, \& Sardiman, 2016, p. iii).

\section{Indonesian-ness and Papuan-ness in His- tory Textbook of 2013 Curriculum for Senior High School Students}

The textbook, as a handbook, is used to facilitate the implementation of learning. In connection with the history subject, the textbook is used for providing history education (Mulyana, 2013, pp. 78-79). In this research, the researchers have set the limitation that the textbook used was Indonesian history learning textbook for grade $\mathrm{X}$, XI, and XII students of senior high school of 2013 Curriculum published by the Ministry of Education and Culture of the Republic of Indonesia. The selection of the textbook was based on the consideration of an official book published by the government so that the government's mission in interpreting historical narratives is expected to be visible and easily analyzed.

The researchers gave meaning to the narratives in the Indonesian history textbook used by grade X, XI, and XII students of senior high school. The meaning was carried out by using two main concepts, namely Indonesian-ness (Indonesia) and Papuan-ness (Papua). Researchers considered that these two concepts contain ideologization in providing meaning to historical events narrated in the history textbook. These two concepts were then mapped into three themes represented in the Indonesian history textbook concerning the relations between Indonesia (Indonesian-ness) and Papua (Papuanness), namely the issues of ethnic nationalism, nationalism, and national integration. 


\section{Ethnic Nationalism Theme}

Ethnic nationalism is defined as the spirit of the formation of ethnic identity awareness. Ethnic nationalism in this research concerned the narratives or construction about Papua (Papuan-ness). There were also dynamics in the diversity of ethnic groups in Papua as well as its cultural systems. The conflict was considered as a regular thing that appears as a result of differences in views or thickening the awareness of tribal identity. Ethnic conflicts in Papua contained the elements of ethnic nationalism and indigenous people. Ethnic nationalism, an ethnic unit that lives in a certain area (Papua) and wants to separate itself from the state (RI), and indigenous people who live in a certain area and wants greater autonomy from the ruling state to protect customary land (Afwan, 2015, pp. 55-57).

The lack of narratives concerning ethnic nationalism in the Indonesian $\mathrm{Na}$ tional History learning textbook for senior high school students has been found from 1975 until the reform era. However, it does not mean there are no historical phenomena concerning ethnic nationalism in Indonesia. The authors of the textbook placed it as phenomena of nationalism. According to Purwanto (2006, p. 182), the dynamics of the formation of Indonesian identity goes hand in hand with ethnic identity (ethnic nationalism). Indonesianness and ethnic nationalism has undergone a process of transformation in synergy to shape each other's identities without having to contradict each other. In the perspective of Purwanta (2012, pp. 119120), history textbook should explain the dynamics of the transformation without eliminating the diversity aspects of the identity of each ethnic.

Based on the researchers' analysis on the theme of ethnic nationalism in Indonesian history textbook for Class X, 3rd Printing of 2016 (Revised Edition) is as follows: in Chapter I: "Tracing Early Civilizations in Indonesian Archipelago", a narrative of Papuan-ness appears in the Melanesoid race. In connection with the Melanesoid race, the textbook explains:
(Gunawan., Lestariningsih \& Sardiman, 2016, p. 37)

\begin{abstract}
Another race in Indonesian Archipelago is the Melanesoid race. They are scattered in the Pacific Ocean on the islands located in the east of the Irian and the continent of Australia. In Indonesian Archipelago, they live in West Papua, Ambon, North Maluku and East Nusa Tenggara. Together with Papua-New Guinea and Bismarck, Solomon, New Caledonia and Fiji, and Vanuatu, they are classified as Melanesoids.
\end{abstract}

What needs to be criticized from the narrative is the term "Irian," which is still used. It should be replaced by the term "Papua" which is following the development of the term in Reformasi era. Furthermore, it is also necessary to add the word "Papua (region)" to mention the Province of Papua and to clarify the narrative because it only mentioned, "West Papua" (West Papua Province). It seems the authors aware of the lack of narrative about Papua so that the word "Papua" is included in the section "Observing the Environment." "... the earthquake and tsunami that occurred in Aceh, earthquake in Yogyakarta, in Papua and other regions, including several volcanoes that erupted" (Gunawan, Lestariningsih, \& Sardiman, 2016, p. 9).

Moreover, concerning the view of local identity, the people who live in the Indonesian archipelago, according to the textbook, are represented as people who cannot accept foreign influences easily. The local community in the archipelago is described as people who have local genius. So, they give birth to various forms of assimilation, acculturation, and even syncretism. Local genius, according to Wales (in Utami \& Widiadi, 2016, p. 112) is the ability of local culture to deal with the influence of foreign cultures when the two cultures are related. According to the narrative of a history textbook for grade $\mathrm{X}$, "Acculturation of Indonesian Archipelago and Hindu-Buddhist Cultures" is in the form of building art, fine art and sculpture, 
performing arts, literary and literary arts, belief systems, government systems, and architecture (Gunawan, Lestariningsih \& Sardiman, 2016, pp. 157-164). Next in Chapter III E: "Acculturation and Development of Islamic Culture" include building art, sculpture, literacy and literary arts, arts, and calendars (Gunawan, Lestariningsih, \& Sardiman, 2016, pp. 239-249).

Next, in Chapter II: "Traders, Authorities and Poets of the Classical Period (Hinduism and Buddhism)," Section B of the Kingdoms in the Hindu-Buddhist Period. Hindus-Buddhist kingdoms based on position include Kalimantan Island (Kutai); Sumatra (Sriwijaya and Kapur City); Java Island (Tarumanegara, Kalingga, Ancient Mataram, Kediri, Singhasari, Majapahit), Bali Island (Buleleng and Warmadewa Dynasty). The narrative about the Land of Papua or the ethnic nationalism of Papua does not have an important (broad) narrative in relation to the development of the Hindu-Buddhist kingdom. The description related to Papua is only briefly discussed, that is, part of $\mathrm{Pa}$ pua was under the authority of the Majapahit Kingdom. The narrative about the greatness of the Majapahit Kingdom during the reign of King Hayam Wuruk and Patih Gajah Mada, which is related to Papua, is as follows: (Gunawan., Lestariningsih \& Sardiman, 2016, p. 138).

According to Kakawin Nagarakretagama, Canto XIII-XV, Majapahit territory includes Sumatra, Malay Peninsula, Borneo, Sulawesi, Nusa Tenggara Islands, Maluku, Papua, Tumasik (Singapore) and most of the islands of The Philippines. Majapahit also had connection with Campa, Cambodia, Siam, Southern Burma, Vietnam. It also had sent its ambassadors to China.

Meanwhile, in Chapter III: "Islamization in Indonesian Archipelago", Sub-Chapter C concerning "Islam Enters the King's Palace," according to the narrative, Islamic kingdoms in Papua include: (1) Waigeo Kingdom; (2) Misool Kingdom; (3) Salawati Kingdom; (4) Sailolof; (5) Fatagar Kingdom; (6) Rumbati King- dom consisting of Atiati, Sekar, Patipi, Arguni, and Wertuar Kingdoms; (7) Kowiai Kingdom (Namatota); and (8) Kaimana Kingdom (Gunawan, Lestariningsih, \& Sardiman, 2016, pp. 229-231). In the context of Islamization in Papua, the narrative, according to the history textbook for senior high school students, is as follows (Gunawan, Lestariningsih, \& Sardiman, 2016, pp. 231).

The process of Islamization in Papua, especially on the west coast, occurred in the middle of the 15th century, which was influenced by Islamic empires in Maluku (Bacan, Ternate, and Tidore). It is supported by its strategic location, which was the spice trade route in the world.

Furthermore, based on the researchers' analysis of the Indonesian history textbook for Grade XI students of senior high school, 1st Semester, 1st Printing of 2014 is as follows: in Chapter 2 concerning "War Against Colonialism" - the narrative of Papuan-ness (Papua) is completely absent. However, local narratives appear in other regions in the Indonesian archipelago, such as Aceh, Banjar, Bali, Banten, Batak, Goa, Maluku, Java, Riau, and Tondano (Sardiman and Lestariningsih, 2014, pp. 62-137). Then, in Chapter 3 concerning "Building Indonesian Identity," - the narratives about Papuanness (Papua) are not presented (Sardiman and Lestariningsih, 2014, pp. 138-203).

Next, based on researchers' analysis of Indonesian history textbook for Grade XI students of senior high school, 2nd Semester, 2nd Printing of 2017 (Revised Edition), the narratives include Chapter 5 concerning "The Tyranny of the Rising Sun," Chapter 6 regarding "Indonesian Independence" and Chapter 7 relating to "The Revolution to Uphold the Principles of Unitary State of the Republic of Indonesia". The narratives concerning Papuanness (Papua) construction only appear in Chapter 7, Sub-Chapter B, 11th point (Round Table Conference), in the sentence: "West Irian problem will be resolved a year later, after the recognition of 
sovereignty" (Sardiman and Lestariningsih, 2017, p. 199).

\section{Nationalism Theme}

According to Mulyana (2013, p. 81), nationalism is a political concept. If it is associated with the approach of the writing of the Indonesian National History textbook for senior high school students, periodization uses a more political approach or political structure (history). The dominant characteristic in political history is the study of power activities (organizations) in society in the past, such as the kingdom. It can be seen in the periodization used and the description of the material. In the Grade X textbook, Chapter II B discusses the "Hindu-Buddhist Kingdoms," with details covering many kingdoms such as Kutai, Tarumanegara, Kalingga, Sriwijaya, Ancient Mataram, Kediri, Singhasari, Majapahit, Buleleng, Warmadewa Dynasty in Bali, Tulang Bawang and Kota Kapur Kingdoms. Then, in Chapter III: "Islamization and Cross-Culture in Indonesian Archipelago," Sub-Chapter C: Islam Enters the King's Palace narrates Islamic kingdoms in Sumatra, Java, Borneo, Sulawesi, North Maluku, Papua and Nusa Tenggara (Gunawan, Lestariningsih, \& Sardiman, 2016).

The description of the kingdoms in the Indonesian archipelago implies that before the formation of the Republic of Indonesia in 1945, there was a fully sovereign power institution in Indonesia, namely kingdom. Many kingdoms had built a connection that created a network caused by communication through sea transportation and activities such as shipping and trading. Shipping and trade activities have made the Indonesian archipelago region as part of the trade network. Even, it was included as one of the bustling world trade areas. As a consequence, many kingdoms in the Indonesian archipelago turned into busy trade centers.

According to Kartodirdjo (1994, p. 3 ), concerning the concept of nationalism as an ideology (principles of freedom, unity, equality, and personality), the discus- sion of nationalism at the beginning of the nationalist movement can be focused on the issues of identity awareness, the formation of solidarity through the process of integration, and organizational mobilization. The writing of the Indonesian history textbook has a connection with the perspective of nationalism. From the standpoint of Mulyana (2013, p. 81), the elements of nationalism as an ideology are quite coloring the structure of the writing of the Indonesian history textbook for senior high school students so far. Meanwhile, the narrative concerning nationalist movement organization in the Indonesian history textbook for Grade XI students of senior high school, 1st Semester, is included in Chapter III: "Building Indonesian Identity," Sub-Chapter B: Analyzing the Struggle of Nationalist Movement Organizations. In detail, these organizations include Early Movement Organizations, Religious Organizations, Youth Organizations, Women Organizations, Indonesian Communist Party (PKI), Indonesian Union (Perhimpunan Indonesia): Political Manifesto, Taman Siswa, and Labor Organizations (Sardiman and Lestariningsih, 2014). The emergence of nationalist movement organizations in the early twentieth century was spearheaded by educated or modern Indonesian elite as the products of western education. Therefore, it can be said that nationalism in Indonesia could not be separated from the influence of westernization carried out by the Dutch East Indies government through education for the natives.

In this context, deterministic construction can be understood as progress in presenting the history that culminates in the triumph of the modernity of the nation -state, namely the western way of thinking or ideal way of life (culture). This view looks at the critical role of intellectuals (modern elites) as the result of western education in Indonesia (Purwanta, 2012, p. 114).

According to Mulyana (2013, p. 83), the Indonesian nationalist movement in the historiography description of a history textbook for senior high school shows 
a historical continuity. Nationalism became a driving ideology in Indonesian history, especially since the ideology became an idea in the early 20th century until the effort to maintain independence. The continuity shows figures who have been involved from the very beginning, the idea of nationalism was introduced as well as from the birth of the proclamation of independence to the revolutionary period. In general, these nationalist figures became the drivers of Indonesian history until the independence revolution period (1945-1949).

\section{National Integration Theme}

The integration of a nation is essential in the life of the nation and state. Integration has a function to give birth to a powerful national force. Thus, all problems that arise can be faced together. The Republic of Indonesia is a concrete manifestation of the process of national integration. The idea of Indonesia as a manifestation of a nation-state did not appear until the early twentieth century. However, the process towards that idea has been conducted since centuries ago when the Islands of Indonesia were still independent territories. The territory of the Republic of Indonesia is the former Dutch colonial territory. Still, Indonesian-ness is not a colonial gift, but the awareness of the nation's children forged by the same fate, historical similarity, and shared ideals (Zuhdi, 2017).

According to Sjamsuddin (in Purwanta, 2012, p. 119), theoretically, national integration contains two main elements, namely vertical integration relating to relations between the elite and the people and horizontal integration related to regional socio-cultural dynamics and the creation of cohesive relationships with other regions nationally. From a theoretical point of view, the authors of the textbook explain more about vertical integration and very less on horizontal integration.

The understanding of the history of shipping and trade networks in the Indonesian archipelago had an essential key in understanding the history of Indonesia as a unitary state that was later formed. The communication network that had been developed in the Indonesian archipelago through shipping and trade activities has formed integration. According to the history textbook for Grade X students of senior high school, the narrative of "The Formation of the Nusantara Network through Trade" is included in Chapter II C (Gunawan, Lestariningsih, \& Sardiman, 2016, pp. 151-156).

The formation of the Nusantara network through trade is narrated as follows: (Gunawan, Lestariningsih, \& Sardiman, 2016, p. 151).

Integration centers in Indonesian archipelago take place through the mastery of the sea. The integration centers are then determined by expertise and concern for the sea, so that new developments occur, at least in two ways, namely: (i) the growth of trade routes that pass through strategic locations on the coast, and (ii) the ability to control political and military traditional rulers (kings) in controlling the main routes and trade centers in the Indonesian archipelago. Therefore, the preconditions to be able to master the trade routes and centers are determined by two important things, namely attention or perspective and the ability to control the sea .

Furthermore, the narrative of the Indonesian archipelago integration process is constructed in Chapter III F, which includes the role of the ulema in the integration process, the role of inter-island trade, and the role of language. The construction of national integration in the textbook is narrated as follows: (Gunawan., Lestariningsih \& Sardiman, 2016: 250)

... The process of integration of Indonesia turned out to be going on for quite a long time and even started from the beginning of Before Christ era. In the 16th century, the process of the integration of Indonesian people began to experience rapid progress since the Islamization process. ... Ulemas from 
Minangkabau, for example, have succeeded in converting our brothers in Sulawesi, Sulawesi's ulemas have also played a role in Islamizing our brothers in Bima, Nusa Tenggara, Riau Islands and so on, as well as ulemas in East Java have Islamized Ternate. and Tidore...

According to Kartodirdjo (in Mulyana, 2013, p. 82), integration is the key concept in Indonesian history. The myth that was built from the dynamics of the formation of Indonesia by providing an interpretation that the idea of Indonesia as a regional and ideological unity had already existed since a long time ago. In fact, Indonesia, as a nation, was formed since the Proclamation of Independence on August 17th, 1945.

The researchers' analysis concerning the theme of national integration in an Indonesian history textbook for Grade XII students of senior high school, 2nd Semester of 2018 (Revised Edition) is as follows: the importance of awareness of national integration can be related to the potential for conflict in several regions in Indonesia today. Therefore, the importance of learning history that contains learning materials and is designed to sharpen students' knowledge competence. Indonesian history subject equips students with knowledge about the dimensions of space and time of Indonesian history dynamics, skills in presenting the knowledge that is mastered in a concrete and abstract manner, as well as an attitude of appreciating the services of heroes so that the mindset of students who are aware of history is formed.

Therefore, in the Indonesian history textbook for Grade XII students of senior high school, it is explained that the national integration narrative is constructed from the nation's disintegration narrative. In Chapter I: "The Struggle to Face the Threat of Disintegration of the Nation", at the beginning the quote "The greatest enemy of our nation is not from outside, but the threat of disintegration that comes from inside" (Abdurakhman, Pradono, Sunarti, \& Zuhdi, 2018, p. 1). The threats of nation's disintegration in the period of 1945-1965 in the form of upheaval and conflict are divided into three, namely: (1) incidents of conflict and upheaval related to ideology, such as (a) the PKI rebellion in Madiun in 1948, (b) DI / TII rebellions in West Java from 1948 to 1962, in Central Java from 1950 to 1951, in South Sulawesi from 1953 to 1965, in South Kalimantan from 1954 to 1963, in Aceh from 1950 to $1959 / 1962$, and (c) 30th of September Movement by PKI in 1965; (2) conflict and upheaval events related to interests, such as (a) the APRA rebellion in 1949, (b) Andi Aziz incident, and (c) RMS rebellion; and (3) incidents of conflict and upheaval related to the government system, such as (a) PRRI and Permesta rebellions, (b) the issues of the Federal States and BFO (Abdurakhman, Pradono, Sunarti, \& Zuhdi, 2018, pp. 229).

One function of history is giving educational use, which implies taking wisdom from past experiences and its relevance to the present. The construction of national integration in Papua appears in the narratives of conflict-prone areas in Indonesia. Papua is one of many conflictprone areas, besides West Java, Central Java, DKI Jakarta, North Sumatra, and Central Sulawesi. However, the narrative of the conflict in Papua is not widely described. Furthermore, national integration in Papua was also constructed through the example of unifying figures or national heroes from Papua. However, the Grade XII textbook only presents three national heroes from Papua, namely Frans Kaisiepo, Merthen Indey, and Silas Papare (Abdurakhman, Pradono, Sunarti, \& Zuhdi, 2018, pp. 34-37). One of the national heroes from Papua who is not discussed in the textbook is Johanes Abraham Dimara. The role of Johanes Abraham Dimara in the struggle for integration of Papua into the Republic of Indonesia should also be featured in the Indonesian history textbook (Sukmawati, 2000).

Another narrative about Papua is the liberation of West Irian (Papua) that has become one of the political issues that 
have continued to reverberate since the Proclamation of Indonesian Independence on August 17th, 1945. During the negotiations of the Round Table Conference (KMB) in 1950, the problem of West Irian (Papua) submission was suspended a year later. However, until 1960 the problem of West Irian could not be resolved by the Netherlands and Indonesia diplomatically even though the United Nations had intervened. Finally, President Sukarno, on 19 December 1961, in the middle of a great meeting in Yogyakarta, issued Tri Komando Rakyat (Trikora) - a command for a military confrontation with the Dutch. The contents of the Trikora are: (1) prevent the Dutch from forming a puppet State of West Papua; (2) raise the red and white flag (Indonesia's national flag) in West Papua; and (3) prepare for mass mobilization as an attempt to defend Indonesia's independence and unity (Abdurakhman, Pradono, Sunarti, \& Zuhdi, 2018, p. 94). One of the effects of the Trikora was the New York Agreement, which was signed on August 15th, 1962 by the Netherlands and Indonesia. The main point of the New York Agreement is as follows:

... the submission of government in Irian from the Dutch to the United Nations. For this purpose, the United Nations Temporary Executive Authority (UNTEA) was formed, which would then submit West Irian to the Indonesian government before May 1st, 1963. Under the New York Agreement, the Indonesian government had an obligation to hold the Act of Free Choice (Pepera) or referendum in West Irian before the end of 1969 with the provisions that both parties must accept whatever results from the Act of Free Choice. (Abdurakhman., Pradono., Sunarti. \& Zuhdi, 2018: 95).

The next step is to restore Dutch Indonesian relations by reopening the embassies of each country. Subsequently, the transfer of power of the Government of West Irian from UNTEA was formally submitted to the Government of the Republic of Indonesia in Hollandia (Kota
Baru/Jayapura).

As a follow up to the New York Agreement, the Government of Indonesia carries out the task of implementing the Act of Free Choice (Pepera). The Indonesian government ran in three stages. These three stages were successfully carried out by the Government of Indonesia, and the results of the act were then brought by Ambassador Ortis Sanz to New York to be reported to the UN Security Council General Assembly. On 19 November 1969, the 24th General Assembly of the United Nations accepted the results of the Act of Free Choice, which had been conducted by Indonesia because it was following the contents of the New York Agreement. Since then, Indonesia regained West Irian (de jure and de facto) as part of the Unitary Republic of Indonesia (Abdurakhman, Pradono., Sunarti. \& Zuhdi, 2018: 95).

During the administration of President Susilo Bambang Yudhoyono, one of the efforts to resolve internal conflicts was the conflict that occurred in Papua. The narrative in the Indonesian history textbook of Grade XII is as follows.

... the efforts to resolve conflicts in $\mathrm{Pa}$ pua also prioritize aspects of dialogue and efforts to improve people's welfare. The lack of justice for the people of $\mathrm{Pa}$ pua has led to resistance and the desire of some people to separate themselves from the Republic of Indonesia. The attention of the government should naturally be given more to increase the economic side and empower the human resources of the people who live in this region through the provision of training to improve their skills in agriculture and understanding of the bureaucracy. Besides, it is also because Papua Province has large natural resources, especially in the mining sector. Related to that, President Susilo Bambang Yudhoyono also issued a special autonomy policy for Papua. Special autonomy is expected to provide partisanship, protection, and empowerment to indigenous Papuans. The government supports the policy through the flow of funds which was 
large enough so that the people of $\mathrm{Pa}$ pua can enjoy a sense of security and peace during rapid development "(Abdurakhman., Pradono., Sunarti. \& Zuhdi, 2018: 180).

\section{CONCLUSION}

History subject is one of the crucial tools or media to instill discourse on state ideology and national identity. One of the instruments used in this practice is the history textbook. The compilation of historical materials in the Indonesian National History textbook of the 2013 Curriculum is inseparable from the influence of government political policy. The curriculum is one part of governmental policy in the field of education. Therefore, the selection of content (material) and the reconstruction of historical sources in the form of interpretation will be influenced by political factors from the government. One influence on the textbook is the ideology and identity of the state. Indonesian history textbook represents various state ideologies. The ideologization forms in the Indonesian national history textbook in the 2013 curriculum include Nationalism (Indonesian), and Ethnic Nationalism (Papuan). Nationalism (Indonesian-ness) and Ethnic Nationalism (Papuan-ness) are political concepts. If the ideas of politics are linked to the approach or structure of the writing of national history textbooks for senior high school students, then it uses a more political (historical) approach.

The discourse on the relations between Indonesia and Papua developed in the Indonesian history textbook of 2013 Curriculum for senior high school students is represented in the themes of Ethnic Nationalism, Nationalism, and National Integration. The construction of Papuan or ethnic nationalism appears to be in the use of the words: Irian, Papua, West Papua, Melanesoid, and narratives of Islamic empires in Papua. Meanwhile, Indonesian-dominant construction in the Indonesian history textbook is represented in the themes of nationalism and national integration.

\section{REFERENCES}

Aditjondro, G. J. (2000). Cahaya Bintang Kejora: Papua Barat dalam Kajian Sejarah, Budaya, Ekonomi, dan Hak Asasi Manusia. Jakarta: Elsam.

Abdurakhman., Pradono, A., Sunarti, L., \& Zuhdi, S. (2018). Sejarah Indonesia SMA Kelas XII, Cetakan Ke-2, Edisi Revisi. Jakarta: Kementerian Pendidikan dan Kebudayaan Republik Indonesia.

Afwan, B. A. (2015). Mutiara Terpendam Papua: Potensi Kearifan Lokal untuk Perdamaian di Tanah Papua. Yogyakarta: Sekolah Pascasarjana UGM.

Budiono, H., \& Awaludin, A.F. (2017). Perkembangan Historiografi Buku Teks Sejarah Di Indonesia Masa Orde Baru Hingga Reformasi. Jurnal Efektor, 30(1), 36-43.

Gunawan, R., Lestariningsih, A.D., \& Sardiman. (2016). Sejarah Indonesia SMA Kelas X Cetakan Ke-3, Edisi Revisi. Jakarta: Kementerian Pendidikan dan Kebudayaan Republik Indonesia.

Hasan, S. H. (2012). Pendidikan Sejarah Untuk Memperkuat Pendidikan Karakter. Jurnal Paramita, 22(1), 81-95.

Kaisiepo, M. (1999). Ke-Irian-an dan KeIndonesia-an: Mengkaji Nasionalisme dalam Konteks Lokal. In Palit, D. I. (Ed.). Dinamika Nasionalisme Indonesia. Salatiga: Yayasan Bina Darma.

Kartodirdjo, S. (1994). Pembangunan Bangsa tentang Nasionalisme, Kesadaran dan Kebudayaan Nasional, Yogyakarta: Aditya Media.

Meteray, B. (2012). Nasionalisme Ganda Orang Papua. Jakarta: PT. Kompas Media Nusantara.

Mulyana, A. (2013). Nasionalisme dan Militerisme: Ideologisasi Historiografi Buku Teks Pelajaran Sejarah SMA. Jurnal Paramita, 23(1), 78-87.

Purwanta, H. (2012). Wacana Identitas Nasional: Analisis Isi Buku Teks Pelajaran Sejarah SMA 1975-2008. Jurnal Paramita, 22(1), 108-121.

Purwanta, H. (2013). Militer dan Konstruksi Identitas Nasional: Analisis Buku Teks Pelajaran Sejarah SMA Masa Orde Baru. Jurnal Paramita, 23(1), 88-102.

Purwanto, B. (2006). Gagalnya Historiografi Indonesia?!. Yogyakarta: Ombak. 
Rahab, A. (2006). Operasi-Operasi Militer di Papua: Pagar Makan Tanaman?. Jurnal Penelitian Politik, 3(1), 3-23.

Sardiman and Lestariningsih, A., D. (2014). Sejarah Indonesia SMA Kelas XI Semester 1 Cetakan Ke-1. Jakarta: Kementerian Pendidikan dan Kebudayaan Republik Indonesia.

Sardiman dan Lestariningsih, A., D. (2017). Sejarah Indonesia SMA Kelas XI Semester 2 Cetakan Ke-2, Edisi Revisi. Jakarta: Kementerian Pendidikan dan Kebudayaan Republik Indonesia.

Sinaga, R. (2013). Masa Kuasa Belanda di Papua 1898-1962. Jakarta: Komunitas Bambu.

Sukmawati, C. (2000). Fa Ido Ma , Ma Ido Fa: Lintas Perjuangan Putra Papua J.A. Dimara. Jakarta: P.T. Sahaprint.
Suryadi, A., Hayat, B., Rustana, C., \& Abduhzen, M. (2014). Pendidikan untuk Transformasi Bangsa: Arah Baru Pendidikan untuk Perubahan Mental Bangsa. Jakarta: PT. Kompas Media Nusantara.

Utami, I. W. P., \& Widiadi, A. N. (2016). Wacana Bhineka Tunggal Ika Dalam Buku Teks Sejarah. Jurnal Paramita, 26 (1), 106-17.

Widjojo, M. S. (Ed.). (2009). Papua Road Map: Negotiating the Past, Improve the Present and Securing the Future. Jakarta: LIPI \& Yayasan Tifa \& Yayasan Obor Indonesia.

Zuhdi, S. (2017). Integrasi Bangsa Dalam Bingkai Keindonesiaan. Jakarta: Wedatama Widya Sastra. 